\title{
CORRELATIONS BETWEEN PHYSICAL EDUCATION TRAINING IN THE FINAL YEARS OF HIGH-SCHOOL AND PHYSICAL EDUCATION TRAINING AT UNIVERSITY
}

\author{
Vladimir Ivanov \\ Medical University of Sofia
}

\begin{abstract}
Physical education is a purposeful process of complete physical formation of a person, in accordance with the requirements of a healthy lifestyle. Our aims are to study the students' attitudes towards the organization, the contents, and the results achieved in the process of physical education during the final years of high school and the opportunities for further continuation and development of these skills and knowledge at higher education institutions. Methods of the experiment include six initial tests with students from the Medical university - Sofia, aiming to assess the strength of their upper and lower limbs and a survey with 15 questions divided into two sections regarding the quantity, organization, the content and the results achieved in the process of high-school sports education and the attitudes of students towards this process at university. The results showed that the fitness levels of survey participants were relatively high considering the fact that for the most part the respondents practiced a sport outside the regular high-school program or were competitors. The teaching process of physical education in the high school system relies on fairly good facilities and physical education facilities at the university level are even better. Student motivation to participate in sports classes in high school provide a negative trend, other claim that they enjoyed spending time with classmates while really small percent participated in order to develop their motoric skills and habits. A similar trend can be observed at the university level, as nearly half of the students participate in order to fulfill their obligations towards the horrarium required, and very low percent attend because they want to meet new colleagues.
\end{abstract}

Key words: physical education, teaching process, correlation, high school education, higher education, university, students, activity

\section{INTRODUCTION}

Physical education training at the university level is to a large extent a continuation of the training conducted in the final years of high school education, the training activities of sports clubs, and the family influence. In reality, however, the level of each individual's development and the specifics and achievements in this area can be mostly attributed to the high school education system with its respective structure, content, and methodology.

This system aims to develop the future university students regarding their personality traits, acquired knowledge, skills and habits, preferences and ambitions. This system nurtures a need for individual physical development, physical activity, and technical skills. These goals subsequently carry to higher education institutions and become the driving force behind students' ambitions for growth and success in this area. It is believed that the latter is to a great extent a function of the former.

The genetically predetermined pattern and tendency of the age-related development of motor abi- lities does not change, but the active pedagogical influence helps in their development at a higher level. Therefore, it is important to make full use of the methods and means of physical education and sport included in the compulsory preparation for students. (Borisov, 2014)

Physical education is a purposeful process of complete physical formation of a person, in accordance with the requirements of a healthy lifestyle. (Rachev, Margaritov, 1994).

Goals of the survey: The survey aims to study the students' attitudes towards the organization, the contents, and the results achieved in the process of physical education during the final years of high school and the opportunities for further continuation and development of these skills and knowledge at higher education institutions.

Survey tasks:

1. Determining the major sports that students took during the final high school years and the 
attitudes towards them.

2. Assessment of the opportunities that high-school education provided for developing the technical skills in the respective sports considering the training conditions provided by the school and the teacher's level of instruction.

3. Students' self-assessment of their own sports class participation in high school and the results achieved.

4. Motivation for active participation and further improvement in sports classes at higher education institutions.

\section{METHODOLOGY}

Study group: The group consisted of first-year students at the Medical University of Sofia of the two genders who participated in mandatory group training classes of physical education for the duration of two semesters in 2018-2019. The group included 66 female and 14 male students.

Table 1. Average values of the initial test results for males and females. (Brogli, Petkova, 1988)

\begin{tabular}{|l|l|l|l|l|l|l|}
\hline & $\begin{array}{c}\text { Right-hand } \\
\text { strength }\end{array}$ & $\begin{array}{c}\text { Left-hand } \\
\text { strength }\end{array}$ & $\begin{array}{l}\text { Number of push- } \\
\text { ups per 30 seconds }\end{array}$ & $\begin{array}{c}\text { Number of } \\
\text { sit-ups per 30 }\end{array}$ & $\begin{array}{c}\text { Standing } \\
\text { long jump }\end{array}$ & Grade \\
\hline Female & $28.38 \mathrm{~kg}$ & $26.90 \mathrm{~kg}$ & 31.65 reps. & 33.10 reps. & $159.40 \mathrm{~cm}$ & Very good 5 \\
\hline Male & $48.60 \mathrm{~kg}$ & $45.80 \mathrm{~kg}$ & 35.70 reps. & 32.30 reps. & $196.2 \mathrm{~cm}$ & Very good 5 \\
\hline
\end{tabular}

In addition, we approached the study group by means of a survey regarding the quantity, organization, the content and the results achieved in the process of high-school sports education and the attitudes of students towards this process at university. The survey included 15 questions and was divided into two sections. The first section focused on physical education in the final years of high school, and the second one focused on the motivation of the students to practice sports during their education at the Medical University of Sofia.

Answers to questions regarding the following were analyzed:

1. The current state and the results from high school physical education:

- Quantity of instruction - number of classes per week and percentage of classes that were attended by the students.

- Contents of physical education classes - types of sports studied and sport activities performed. Practicing a sport outside school.

- Facilities and motivation to participate in the learning process regarding physical education in school.

- Results achieved - levels of physical indicators
Object of the survey: The teaching process of physical education in high schools and its connection to the physical education teaching process at the Medical University of Sofia.

Objectives of the survey: To improve the methodology organization and contents of Physical Education at the Medical University of Sofia as further continuation of the high school education process. Survey methodology: During the first semester, first-year students were subjected to initial tests aiming to assess the strength of their upper and lower limbs. (Bozhkova, 2012) The tests included:

- Right-hand strength - measured by means of an electronic dynamometer

- Left-hand strength - measured by means of an electronic dynamometer

- Number of push-ups per 30 seconds

- Number of per 30 seconds

- Standing long jump (two tries)

achieved regarding the existing control norms and technical skills for the studied sports. Assessment of teaching and final grade in physical education in secondary education.

2. The current state and the results of physical education at the higher education level:

- Acquiring theoretical and practical knowledge and skills on behalf of the students during physical education classes at higher education institutions.

- Student motivation to participate in the learning process of physical education and assessment of facilities and teaching.

- Whether or not the grade for physical education classes adequately reflects the students' results.

- Student attitudes towards the contents and the methodology of teaching at the university level.

\section{ANALYSIS AND RESULTS}

Physical Education as a curriculum subject contributes greatly to the levels of theoretical and practical preparation, which in turn significantly affect the final outcomes of university education and the later realization of students. To a large extent, it reflects the system and the methods of student preparation in the final years of high-school education. 
The survey results indicated the following:

1. There is a high attendance rate of physical education classes, $84 \%$, and schools focus on team sports predominantly (basketball, volleyball, and soccer above $63 \%$ ) due to the larger class size. At universities, physical education provides a variety of activities and includes more individual sports, such as tennis, skiing, kayaking, etc. University education also provides an opportunity, for those who practice actively, to join teams or train outside of university, which makes the physical education process more attractive to the students.

2. The fitness levels of survey participants were relatively high considering the fact that for the most part the respondents practiced a sport outside the regular high-school program (50\%) or were competitors (17\%).

3. The teaching process of physical education in the high school system relies on fairly good facilities (52\%) and physical education facilities at the university level are even better (70\%). This results from the universities' resources to rent, build, and maintain UpToDate sports facilities that comply with the specific requirements for the disciplines offered.

4. The survey respondents rate teaching both at high schools and at universities very highly (above $79 \%$ and $82 \%$ respectively) and express their satisfaction with attending physical education classes $85-91 \%$. This is a good indicator of the quality of teaching at educational institutions in Bulgaria.

5. Answers regarding the student motivation to participate in sports classes in high school provide a negative trend, as $49 \%$ claim that they enjoyed spending time with classmates while only $28 \%$ participated in order to develop their motoric skills and habits. A similar trend can be observed at the university level, as $43 \%$ of the students participate in order to fulfill their obligations towards the horrarium required, and $15 \%$ attend because they want to meet new colleagues. This indicates a shift of the focus of physical education classes.

6. The sports grade earned by $89 \%$ of the survey participants in high school is "excellent", while the results from the initial Eurofit fitness test from the first semester of university indicate a "very good" grade, which does not correspond to the grade from high school.

Table 2. Student attitudes towards the organization, the contents

\begin{tabular}{|c|c|c|}
\hline \multicolumn{3}{|c|}{$\begin{array}{l}\text { Student attitudes towards the organization, the contents, and the results achieved in the process of physical } \\
\text { education training in the final years of high school and the opportunities to continue and further develop this } \\
\text { knowledge and skill at university }\end{array}$} \\
\hline \multicolumn{3}{|c|}{ HIGH SCHOOL PHYSICAL EDUCATION } \\
\hline Questions & \begin{tabular}{|c|} 
Answers \\
\end{tabular} & Results \\
\hline \multirow{3}{*}{ Age groups of respondents } & 19 years & $74 \%$ \\
\hline & 20 years & $21 \%$ \\
\hline & 21 years & $5 \%$ \\
\hline \multirow[t]{2}{*}{ Gender distribution } & Female & $82 \%$ \\
\hline & Male & $18 \%$ \\
\hline \multirow{3}{*}{$\begin{array}{l}\text { Number of academic hours of } \\
\text { physical education per week }\end{array}$} & 1 academic hour & $9 \%$ \\
\hline & 2 academic hours & $67 \%$ \\
\hline & more than 2 academic hours & $24 \%$ \\
\hline \multirow{4}{*}{$\begin{array}{l}\text { Attendance of physical } \\
\text { education classes at high school }\end{array}$} & above $75 \%$ & $57 \%$ \\
\hline & never missed a class of physical education & $27 \%$ \\
\hline & from $25 \%$ to $50 \%$ & $13 \%$ \\
\hline & below $25 \%$ & $3 \%$ \\
\hline \multirow{6}{*}{$\begin{array}{l}\text { Sports disciplines that the } \\
\text { students practiced at high school }\end{array}$} & basketball & $20 \%$ \\
\hline & \begin{tabular}{|l|} 
volleyball \\
\end{tabular} & $47 \%$ \\
\hline & track and field & $13 \%$ \\
\hline & table tennis & $9 \%$ \\
\hline & soccer & $10 \%$ \\
\hline & other sports & $1 \%$ \\
\hline \multirow{3}{*}{$\begin{array}{l}\text { Additional physical training } \\
\text { taken by students }\end{array}$} & Yes, I was a competitor & $17 \%$ \\
\hline & No, I focused on my studies & $33 \%$ \\
\hline & I practiced for pleasure & $50 \%$ \\
\hline
\end{tabular}




\begin{tabular}{|c|c|c|}
\hline \multirow{4}{*}{$\begin{array}{l}\text { Student motivation to } \\
\text { participate in physical education } \\
\text { classes in high school }\end{array}$} & I enjoyed being with my classmates & $49 \%$ \\
\hline & I was interested in the sport & $12 \%$ \\
\hline & I wanted to raise my grade & $11 \%$ \\
\hline & I wanted to develop my motoric skills and habits & $28 \%$ \\
\hline \multirow{4}{*}{$\begin{array}{l}\text { Facilities and conditions for } \\
\text { physical education at high } \\
\text { school }\end{array}$} & Good, but could be further improved & $52 \%$ \\
\hline & Very good conditions & $24 \%$ \\
\hline & Very bad conditions & $4 \%$ \\
\hline & Excellent conditions & $20 \%$ \\
\hline \multirow{3}{*}{$\begin{array}{l}\text { Attitudes towards physical } \\
\text { education classes in high school }\end{array}$} & $\begin{array}{l}\text { I am pleased, but there were not enough classes in order } \\
\text { to consolidate my skills and knowledge }\end{array}$ & $55 \%$ \\
\hline & $\begin{array}{l}\text { I am very pleased; I mastered the necessary skills and } \\
\text { knowledge }\end{array}$ & $30 \%$ \\
\hline & I am not pleased & $15 \%$ \\
\hline \multirow{4}{*}{$\begin{array}{l}\text { Assessment } \\
\text { instruction }\end{array}$} & Excellent teacher & $40 \%$ \\
\hline & I am not pleased with the teacher & $6 \%$ \\
\hline & Very good teacher & $39 \%$ \\
\hline & The teacher needs improvement & $15 \%$ \\
\hline \multirow{2}{*}{$\begin{array}{l}\text { Physical education grade of } \\
\text { respondents }\end{array}$} & Excellent $(6)$ & $89 \%$ \\
\hline & Very good (5) & $11 \%$ \\
\hline \multicolumn{3}{|c|}{ PHYSICAL EDUCATION TRAINING AT UNIVERSITY } \\
\hline \multirow{4}{*}{$\begin{array}{l}\text { What is your assessment } \\
\text { of the physical education } \\
\text { training sessions at the Medical } \\
\text { University of Sofia? }\end{array}$} & The organization and the conduction of classes can be & $5 \%$ \\
\hline & Very good organization and conduction of classes & $24 \%$ \\
\hline & I am not pleased & $1 \%$ \\
\hline & Excellent organization and conduction of classes & $70 \%$ \\
\hline \multirow{3}{*}{$\begin{array}{l}\text { Do you receive the necessary } \\
\text { knowledge (theoretical and } \\
\text { practical) to practice your } \\
\text { sport of choice at the Medical } \\
\text { University of Sofia? }\end{array}$} & I do receive & $91 \%$ \\
\hline & Could be improved further & $8 \%$ \\
\hline & Do not receive & $1 \%$ \\
\hline \multirow{3}{*}{$\begin{array}{l}\text { What is your assessment of } \\
\text { the university facilities where } \\
\text { physical education classes are } \\
\text { conducted? }\end{array}$} & Excellent conditions & $70 \%$ \\
\hline & Very good conditions & $26 \%$ \\
\hline & Good conditions but could be improved further & $4 \%$ \\
\hline \multirow{3}{*}{$\begin{array}{l}\text { What is your assessment of } \\
\text { the teachers who conduct the } \\
\text { physical education classes at the } \\
\text { university? }\end{array}$} & Excellent at conducting sports classes & $82 \%$ \\
\hline & Fairly good & $4 \%$ \\
\hline & Very good performance of obligations & $14 \%$ \\
\hline \multirow{2}{*}{$\begin{array}{l}\text { Do you believe that the amount } \\
\text { of physical education training } \\
\text { sessions in the program of the } \\
\text { university is sufficient? }\end{array}$} & Yes, I do believe it is enough & $62 \%$ \\
\hline & No, one academic class per week is not enough & $38 \%$ \\
\hline \multirow{4}{*}{$\begin{array}{l}\text { What motivates you the most } \\
\text { to attend physical education } \\
\text { training sessions at the } \\
\text { university? }\end{array}$} & Fulfilling my obligations of attendance for the semester & $43 \%$ \\
\hline & Gaining new knowledge and skills & $36 \%$ \\
\hline & Meeting new colleagues & $15 \%$ \\
\hline & Improving my grade & $6 \%$ \\
\hline
\end{tabular}

\section{DISCUSSION AND CONCLUSION}

After analyzing the results from the initial fitness test and the survey answers given by students, the following can be concluded:

1. The fact that the physical education grade form high school does not correspond to the results achieved in the initial fitness tests indicates a problem and raises the question of whether or not the high school grades for physical education are realistic.

2. Motivation and participation of university students in physical education classes can be 
considered another problem. The fact that university students attend sports classes mostly in order to meet the horrarium expectations of the program or to meet new colleagues is an issue of concern.

3. Another negative response comes from a large group of respondents who state that a single academic hour of sport per week in the university program is enough, which indeed is completely insufficient to improve the previously developed skills and habits in the sport of choice.

4. On average, students in Medical university - Sofia have about 90 minutes a week for sport at university, which is far below the sanitary minimum of about 190 minutes on average weekly, according to the US National Association for Sport and Physical Education and 60 minutes daily recommended by the World Health Organization. (Kinov, 2014)

5. The need for changing forms of physical education and sport organization is increasingly prevalent in view of the new demands of the dynamic global economy and the challenges of new technological age. (Lukanova, 2018)

6. In our future scientific work, an additional research will be made to determine the factors and prerequisites that affect the results, similar to the study conducted by (Borukova, Kuleva, Tsarova, 2017).

\section{REFERENCES}

Borisov, L. (2014). Impact of compulsory physical education and sport training on the motor potential of students aged 11 to 14, NSA, Dissertation. // Борисов, Л. (2014).

Borukova, M., Kuleva, M., Tsarova, A. (2017). Factor Structure and Basic Factors of the Sports Preparedness of 15-16 years old National Basketball Competitors. Proceeding book of the International Congress "Applied Sports Sciences" 1-2 December 2017, pp.131-135

Bozhkova, A.(2012). Professional oriented motor preparation for students in the specialty medical rehabilitation, ergotherapist, Monograph, 2012 ARTGRAF, ISBN 978-954-9401-73-8, Sofia.

Brogli, J., Petkova, L. (1988). Statisticheskimetodi v sporta, Medicina I Fizkultura, Sofia, 1988.

Kinov, S. (2014). Out of school activity in the system of physical education and sport (conception, content and forms for realisation). Dissertation.

Lukanova, V. (2018). Problems of the physical education and sport in the modern bulgarian school, The 10th international scientific conference in alma mater 2018 Modern trends of physical education and sport. November, pp.52-55.

Rachev, K., Margaritov, V. (2012). Motor skills in elementary school age, NSA, Sofia. 1994

Corresponding author: Vladimir Ivanov, PhD

Medical University of Sofia

E-mail: vlado.iv.ivanov@gmail.com 